\title{
Crime and Armed Groups in the International and Legal Amazon
}

\author{
Ketiane GUERREIRO ${ }^{1 \odot}$
}

\begin{abstract}
Transnational illicit activities, in addition to the unbridled greed for mineral resources, strongly impact Amazonian territories extending from the Orinoco Mining Arc in Venezuela to northern Brazil, aggravating problems of environmental impacts and border security, due to groups of the armed forces that protect mineral explorers. In Venezuela, megabandas joined the political elite that controls gold mining, as well as members of the Colombian Armed Forces (FARC) and armed military groups representing institutionalised violence, placing Venezuela in second place for murder among South American countries in 2020, with a rate of 45.6 per 100,000 inhabitants. In turn, Brazil reached ninth place, with 19.3 per 100,000 inhabitants. Violent deaths in the North and Northeast regions increased up to a great extent due to clashes between the Red Command and Northern Family factions against the largest group, the First Command of the Capital (PCC), which has more and more Venezuelan members, modifying the criminal modus operandi on the Brazil-Venezuela border. Therefore, Security and Border Defence Plans are indispensable.
\end{abstract}

Keywords: crime, transnational crimes, defence, homicide and security

\section{Introduction}

Located in Latin America, Amazonia Legal ${ }^{2}$ has mineral riches, which generates greed and the presence of social actors for exploration purposes, leveraging the illegal exploitation of gold, mineral ores and precious stones. It happens that in Venezuela, the incentive came from the government itself, although the practice is not legalised and is conditioned for some groups led by those who have government alliances.

The present study aims to discuss the dynamics of armed crime occurring in Venezuela, represented by gangs, megabandas and Fuerzas Armadas Revolucionarias de Colombia, with genesis in Colombia. On the Brazilian side, crime is analysed with criminal faction practices in the border area, being the First Command of the Capital (PCC) with Venezuelan

Lecturer at the State University of Roraima, Brazil, e-mail: ketiguerreirorr@gmail.com

Amazonia Legal refers to the Amazonian territories of Brazil. It covers the states of Acre, Amapá, Amazonas, Pará, Rondônia, Roraima and Tocantins, as well as most of Mato Grosso and some areas belonging to the state of Maranhão. 
members acting in their illicit activities, modifying some characteristics of criminal practices, with characteristics of transnational crimes.

In the 2018 U.S. Department of State's Department of Travel Advisory, Venezuela was assessed as Level 3, with respect to the general crime and security situation. The U.S. State Department rated Caracas as a critical threat site for crimes targeting or affecting the official interests of the U.S. Government. It also considered Venezuela one of the most dangerous countries in the world. Since January 2019, Venezuela has been placed in the worst category: Level 4 - do not travel. ${ }^{3}$

Although official crime figures are not released, unofficial statistics indicate that most categories of crime have increased in Venezuela. The government often tries to refute or repudiate reports of increased crime and homicide rates; however, independent observers broadly reject these claims. Most of Caracas's crime and violence continues to be attributed to mobile street gangs and organised crime groups. ${ }^{4}$

Violent crime is the biggest threat in Caracas, affecting both Venezuelans and foreigners. The NGO Observatorio Venezolano de Violencia (Venezuelan Observatory of Violence, OVV) ranked Venezuela in 2016 as the second most murderous nation (91.8 homicide rate) only after El Salvador (103 homicide rate). ${ }^{5}$ By 2018, Venezuela was expected to take the lead. ${ }^{6}$ After homicide, the crimes of greatest concern in Caracas are kidnappings and robberies, including vehicle thefts, street robberies and home invasions. Increased crime is associated with violent practices in which the criminal profile makes Venezuela itself violent in an institutional way.

Insight Crime magazine emphasises that there is a correlation between Venezuelan state employees involved in criminal actions, through groups of armed civilians. There is a list of distinct groups, which we will mention in this work, with peculiar characteristics that develop their criminal practices throughout the national territory. The primary issue that connects these facts, are the segregation orders of the geographical spaces where mineral resources are present, and thus commanded by high-ranking military officers. In this way, the security forces allied with armed groups, coercively command various mines throughout the country.

As a result of Venezuela's economic crisis, more than 5.6 million people have left the country since $2015^{7}$ - that is, $1 / 6^{\text {th }}$ of the population - and migrated mainly to Colombia, Peru, Ecuador, Chile and Brazil. With access through a single highway that goes to Brazil, countless foreigners log in search of subsistence. There is no way for the authorities of Brazil to know if these individuals have a criminal record or have practiced any illegal activity in their country of origin, due to the lack of a database or agreement between the public security authorities of Venezuela and Brazil.

3 Conor Finnegan, 'US raises travel advisory for Venezuela to highest level: 'Do Not Travel', $A B C$ News, 29 January 2019; U.S. Department of State - Bureau of Consular Affairs, 'Travel Advisory - Venezuela', 28 January 2021.

$4 \quad$ Insight Crime, ‘Colombia y Venezuela: Siameses criminales’, 21 May 2018.

5 El País, 'With 28,479 killings, Venezuela takes second spot on world murder ranking’, 29 December 2016.

6 Renzo Pipoli, 'Venezuela on track to be Latin America’s most violent country in 2018', UPI, 28 December 2018.

(x) Center for Disaster Philanthropy, 'Venezuelan Humanitarian and Refugee Crisis’, 20 September 2021. 
In Brazil, mining practices are unrestrained and disorderly, occupying more and more territorial spaces, especially in the Brazil-Venezuela border, state of Roraima, a place that has an underground with exclusive use of the Union, and is mostly located in Indigenous Lands, which have only the use of the soil. In fact, the Amazon rainforest has been plundered due to covetousness for gold, various minerals and precious stones. It happens that these groups of prospectors carry a history of violence. Thus, crimes such as drug use, illegal possession of weapons, prostitution, murder and assaults have become more constant, social actors from armed crime, criminal organisations with territorial extension throughout the country as the First Command of the Capital (PCC) emerged. ${ }^{8}$

In the urban space of Boa Vista, capital of the state of Roraima, the insertion of Venezuelan members to organised crime PCC, was evidenced in 2021, with the deaths of several foreign members in broad daylight, in dispute over territory in the sale of drugs in the capital.

\section{Orinoco Mining Arc}

The National Strategic Development Zone of the Orinoco Mining Arc (Arco Minero del Orinoco, AMO) was signed in 2016 by President Nicolas Maduro, through Presidential Decree No. 2248, disclosed in the Official Gazette No. 40855. It comprises a territorial extension of $111,843 \mathrm{~km}^{2}$ south of the river Orinoco, corresponding to $12 \%$ of the national territory. Thus the National Strategic Development Zone became established, under the aegis of the National Mining Plan from 2019 to 2025. New social actors emerged under shady agreements with national and international companies, for the precarious predatory exploitation with a high degree of pollution and expropriation of resources, generating a new process in the economy and territorialisation of the geographical space. ${ }^{9}$

The new predatory order of exploitation of mineral resources goes against the constitution of that country, leveraging several crises in power relations, and massive presence of military personnel in the region. It expands violence and occupation of nationals and foreigners in the search for the appropriation of mineral resources in a clandestine way, but at the same time a way institutionalised by government officials and their allies. ${ }^{10}$

\section{Armed groups in Venezuela}

In relation to violence and crime, Venezuela was considered a twin country with Colombia, with an area known for illicit flow and international trafficking. Whereas Colombia represents the largest production of cocaine in the world, and Venezuela, went on to smuggle drugs and weapons. The border space between Colombia and Venezuela has become,

8 State of Roraima has a triple border, comprising Venezuela, Brazil and Guyana.

9 Emiliano Teran Mantovani, 'La minería depredadora en Venezuela: Arco Minero del Orinoco, economías de enclave y Plan Minero Nacional’, Boletín WRM 254, January-February 2021.

10

Ibid. 
especially in the last 15 years, a fruitful space for the operations of groups linked to drug and arms trafficking, as well as a strategic locus for the refuge of illegal armed groups and paramilitaries. This intensification stems largely from Colombian military operations to eradicate illegal crops and demobilise paramilitaries. ${ }^{11}$

Venezuelan authorities believe there are about 10 groups of criminal organisations known as megabands, which operate nationwide, including inside prisons. Armed groups oppose the so-called "Los Pranes", favouring certain prisoners, while the war arsenal is in charge of the state authorities. In addition to transnational crimes, it has to be mentioned that these groups acquire short weapons and weapons of large calibre, AK-47 and R-15, grenades, ballistic vest, with ease. As these groups grow, public security in Venezuela is declining, leaving individual and collective rights and guarantees endangered, with the militares being involved in arms trafficking, violence and corruption. Among the armed groups, what draws most attention is the presence of the National Liberation Army (ELN) and remaining factions of the Revolutionary Armed Forces of Colombia (FARC), indicated by Insight Crime in 2018. ${ }^{12}$

With the permanence of armed groups and government involvement with criminals, the country is known for corruption and institutionalised acts of violence. Criminal lawyer and professor of criminology at the Central University of Venezuela (UCV) Luis Izquiel, analysed crime in Caracas, coming to the conclusion that extortion is the crime that has had the highest growth in the last two years. He also states that armed criminal megabands seek their peace zones, and for this space to occur make use of strategies of violence with weapons of war. When asked why government institutions do not fight criminal organisations in Venezuela, he answered that informally, the government has handed over territorial spaces to these criminal groups, just like fiefdoms where they dominate geographical spaces and commit kidnapping even to police officers. Thus, they play a role in the scenario of terrorism in public spaces and in security areas, as in the case of the Invasion National Guard to steal anti-aircraft and private materials, committing homicides. Bolivarian National Service (SEBIN), became a true political group, becoming aware of the entire system of crime, but remain inert to the criminal practices that occur in Venezuela. ${ }^{13}$

According to Professor Roberto Briceño-León, ${ }^{14}$ there was an increase in police lethality in confrontation with civilians. He said that in 2020, 11,891 people died from violent causes, implying a rate of 45.6 per 100,000 inhabitants. ${ }^{15}$ Despite the fact that it is high, it has to be taken into account that there has been a reduction compared to 2019, when 16,506 people died from violent causes, with a rate of 60.3 per 100,000 inhabitants. He also added:

11 Marília Carolina Barbosa de Souza Pimenta, Strategic and Structural Zones for Illicit Transits (ZEETI): Challenges to the peace zone in South America (Doctoral thesis, PUC/SP, São Paulo, 2016).

12 Insight Crime, 'Venezuela: ¿Un estado mafioso?’, 25 May 2018.

13 TVV Noticias, 'Luis Izquiel analiza el aumento de la violencia armada en Caracas'.

14 Investigator born in Venezuela in 1951. Degrees: Sociology (1974); PhD in Sociology (1984). He has been the coordinator of the Venezuelan Violence Observatory since 2005. Author of more than 20 books, he is currently Professor Emeritus.

15 Portugal Digital, 'Venezuela foi o país da América Latina com mais mortes violentas em 2020', 30 December 2020. 
The number rose to 34 per 100 homicides in 2017, to 72 in 2018 and to 88 in 2019. In 2020, for the first time, there were more deaths at the hands of the police than of criminals; with 101 cases caused by law enforcement officers for every 100 delinquent homicides. Among the 4,231 victims of resistance to authority, 90\% were between 18 and 40 years old, but 82 were only between 12 and 17 years old, in addition to three children under the age of $11 .{ }^{16}$

The omission of crime data in Venezuela is noticeable, despite numerous reports of increased crime and criminal megabands. The groups that make up criminal organisations in Venezuela are identified and have experience in criminal practices. We can describe them. The armed groups that emerged in Colombia have paramilitary training, until mid-2000, fighting the guerrillas, making it a militarised government struggle against terrorist groups, with the main groups being the National Liberation Army (ELN), FARC Dissidents, The People's Liberation Army (EPL), Colombian Mafia, Bolivarian Liberation Forces (FBL) and Bolivarian National Armed Force (FANB).

In principle, Plan Colombia, as the military aid package initiated in 2000 was named, released funded for anti-drug actions, but not specifically to combat the guerrillas. However, after the Terrorist Attacks of September 2001, and the U.S. declaration of war on terror, restrictions on the use of force ended, as both the FARC, the National Liberation Army (ELN) and the paramilitaries were classified as terrorist groups. ${ }^{17}$

Through this research, the testimonies of prisoners in the state of Roraima affirm the presence of armed FARC groups, which occupy Venezuela in areas, carrying out activities to control access to individuals who transit in a certain region, with collusion of the government, effecting the idea of institutionalised violence in the country, initiated since the government of Hugo Chávez. In addition to these armed groups, Venezuela has the Legal Armed Collectives (CAI), which are those who remain in clandestine crime and claim to function in the name of defending the revolution they used to fight for. ${ }^{18}$

According to studies by the Venezuelan Observatory of Violence (OVV), "the use of the war arsenal by the unions in mines is another possible indication of complicity between criminals and uniformed men. In order that these weapons - used exclusively by the Fuerza Armada Nacional Bolivariana - get to the south of the Orinoco, they must pass through several alcabalas (posts) guarded by the Guardia Nacional Bolivariana."19 We can observe the presence of Brazilian criminal organisation in Venezuelan territory. These in turn perform drug barter for weapons, gold and other illicit transactions within this territory, in addition to carrying out the protection of the group with which it has an alliance.

With high war power, the criminal organisations of Venezuela carry out the sale of weapons to Brazilians, now with the new modality of barter quite peculiar. Through an

16 Ibid.

17 Thiago Rodrigues, 'Narcotráfico e militarização nas Américas: vício de Guerra’, Contexto Internacional 34, no 1 (2012), 9-41.

18 Thairi Moya Sánchez, ‘Grupos civiles armados en Venezuela: ¿Actores de un ‘aparato organizado de poder’?’, ANIDIP 6 (2018), 110-144.

19 Observatorio Venezolano de Violencia, 'Bandas que operan al sur de Bolívar adoptan prácticas del pranato carcelario y de las mafias de la construcción’, 11 March 2016. 
interview a police authority in the state of Roraima, who asked for anonymity, revealed the emergence of the sale of drugs from Colombia, carried out by members of the First Command of the Capital (PCC), with access by land, on BR-174, passing through the Amazon; change caused by the closure of the border with the Bolivarian country. The current strategy is to exchange the drug for gold, and this gold for weapons, for the supply of war power in the illegal prospectors in Roraima, since violence and territorial disputes are constant in the region.

Both the permanence of armed groups within the areas destined for mining as well as in the border areas are observed, in which ELN, PCC, FARC and other criminal organisations transit and execute various criminal practices and disputes over territorial spaces and dominance in the sale of drugs. ${ }^{20}$

Going through a scenario similar to that of the neighbouring country, Roraima has been undergoing changes in the degradation of the environment due to mining practices, and the increase in crime due to rivalries in the market of the illegal exploitation of ores. Thus, the intentional violent deaths leveraged in the year 2021, with scenes of lifeless bodies thrown onto the ground on the approaches of roads that give access to prospectors.

According to prison documents in the state of Roraima, Venezuelans are co-opted in the PCC. The same criminal groups are present which operate in Venezuela, ${ }^{21}$ as we can see in the article in the newspaper Folha de Boa Vista, based on official testimony in the legal procedures that deal with the execution of arrests in flagrante. The writing has excerpts that reveal that "at least 740 of their compatriots have joined the faction groups in Roraima in recent years. In addition, the PCC would have made an alliance with the criminal group Trem de Aragua”, ${ }^{22}$

In order to carry out this research, interviews were conducted with the operators of public security. They alleged that members of criminal groups in Venezuela associated with the PCC were identified (called The Syndicate), in particular in the border town of Pacaraima, dealing with drug and weapons transactions. Members of criminal organisations arrested for drug trafficking in possession of a certain amount of gold were observed. It is suspected that the group itself exchanges the drug for gold in the mining companies and later this same gold for weapons in Venezuela.

Former members of the FARC, ELN, Pranatos, Los Soles Cartel and other groups active in Venezuela and now in neighbouring countries were identified in the other municipalities of the State of Roraima. The fact is that the modus operandi of local crime has been modifying and acquiring a new profile due to the new social actors present and transnational crimes. Another similarity with Venezuela was the emergence of PCC members with the prospectors. Fact confirmed in the Operation with the Federal Police, in indigenous land where illegal mining operates. On 13 May 2021, when they were received on Yanomami indigenous land with gunshots, something unusual happened in the conduct of prospectors who generally do not turn to the actions of public security. In this attack,

20 Walter Barrero, 'FARC e ELN: mais dois grupos terroristas em ação na Venezuela’, RenovaMídia, 26 February 2019.

21 Vitor Plácido dos Santos Peres, ‘Análises de Conjuntura’, Grupo de Estudos e Pesquisas em Segurança Internacional (GEPSI), s. a.

22 Folha Web, 'Venezuelanos atuam em papel de liderança no crime organizado em RR', 08 February 2021. 
along with the president of the District Council of Indigenous Health Yanomami and Ye 'kuana (Considi-Y), Junior Hekurari, there were three prospectors killed, five were shot and one Yanomami was injured. According to him, the bodies were taken by the prospectors to the camp where they work. ${ }^{23}$

According to a survey conducted by Hutukara, the PCC and Aragua Train are present in the Yanomami Indigenous Lands, performing a kind of protection for prospectors, as observed in the map, the area of interest and speculation by members of said criminal organisations, according to the matter the PCC is held responsible for 12 attacks in the state of Roraima. ${ }^{24}$

During the field research, I asked the police authority if in fact members of criminal organisations are present in the prospectors. The answer was that "the strategy is to take the drug to the mine, exchange it for gold and this gold is exchanged for weapons at the border of Pacaraima/Venezuela, which will be taken to the mine, in order to carry out the safety of certain owners of deposits".

Within the local criminological context, what draws attention is the use of drugs as a bargaining chip. Due to the crisis in Venezuela and the official closure of the border as a factor that hindered the entry of drugs into Venezuela, their value has considerably increased in the state of Roraima, making it more profitable to exchange drugs for gold and gold for weapons. Thus was the way found by crime to supply the state of Amazonas with weaponry. With the increase in the price of drugs, it became unfeasible to sell drugs in the city to addicts. In this sense, the crime scenario in the state of Roraima and Amazonia has been changing. Neglected by authorities of the State of Roraima until mid-2015, criminal factions modified criminal practices, and modus operandi of the local context, described empirically by public security agencies, intelligence institutions and judiciary. Thus, the involvement of young people as perpetrators of criminal practices was confirmed through reports of the police as well as printed and cyber media. Young people are inserted as victims and possible perpetrators of homicides. ${ }^{25}$

In an interview conducted with the investigative police of the State of Roraima, it was possible to obtain information on practices similar to the Venezuelan faction. The Union operates in a neighbourhood of the capital Boavistense. It charges entrepreneurs a monthly fee to make an alleged security of trades, but these are members of the PCC in the state of Roraima, where there did not use to exist this illicit practice, and who aim to master a field in a certain spatial delimitation and start to charge a monthly fee for trades in general.

\section{Conclusions}

Considering the economic situation of Venezuela and the incentive through presidential decree for the extraction of mineral deposits, in addition to endogenous and exogenous

23 Humanitas Unisinos Institute, ‘Como o PCC se infiltrou nos garimpos em Roraima’, 13 May 2021.

24 Ibid.

25 Ketiane Guerreiro, Gilmara Pinheiro de Andrade and Regys Odlare Freitas, 'O lúdico é matar: homicídio de jovens no estado de Roraima em 2018', IBCCRIM, 2020, 1417-1438. 
factors, the scenario of this country has undergone modifications, with accelerated growth of criminal groups. The institutionalisation of violence is evident through the military members themselves at the behest of the Bolivarian Government. It has segregated the areas of the mining arc, where several armed groups emerged, which act without any form of restriction exerted by the bodies of public security of Venezuela. The situation is further aggravated by exchange of information and criminal practices between members of criminal organisations in Venezuela and Brazil, observed through the testimonies of prisoners for trafficking drugs and weapons.

According to the changes in the dynamics of crime in the State of Roraima and the insertion of new actors in crime - such as the presence of three types of Venezuelan factions that are Trem de Araguá, Sindicato and Cartel de Los Soles - both the foreign members in the PCC expanded as well as the regulations, called "disciplines" of the PCC have been modified, aggregating practices from foreign factions.

Characteristics of transnationality are present in this territorial space where the border is only imaginary. Despite the various agreements in which Brazil is a signatory, it has no control of the dynamics of crime at the border of these countries, especially in the mining regions, which facilitate the recruitment of armed groups to carry out a kind of security and flow of mineral resources in both countries.

Finally, the extraction of ores in the Amazon has been accompanied by several crimes to the environment, and also crimes committed by armed groups, causing a greater sense of economic and social insecurity in the population. Those are especially affected who live on the banks of rivers, for now, with water inappropriate for consumption, their health and feeling of well-being are endangered. The incalculable destruction and depredation to the environment contributes to create a sense of insecurity and alliance between Brazilian, Venezuelan and Colombian armed groups.

\section{References}

Barrero, Walter, 'FARC e ELN: mais dois grupos terroristas em ação na Venezuela'. RenovaMídia, 26 February 2019. Online: https://renovamidia.com.br/farc-e-eln-mais-doisgrupos-terroristas-em-acao-na-venezuela/

Center for Disaster Philanthropy, 'Venezuelan Humanitarian and Refugee Crisis', 20 September 2021. Online: https://disasterphilanthropy.org/disaster/venezuelan-refugee-crisis/

El País, 'With 28,479 killings, Venezuela takes second spot on world murder ranking', 29 December 2016. Online: https://english.elpais.com/elpais/2016/12/29/ inenglish/1483016769_194171.html

Finnegan, Conor, 'US raises travel advisory for Venezuela to highest level: 'Do Not Travel'.' ABC News, 29 January 2019. Online: https://abcnews.go.com/Politics/us-raises-traveladvisory-venezuela-travel/story?id=60699828

Folha Web, 'Venezuelanos atuam em papel de liderança no crime organizado em RR', 08 February 2021. Online: https://folhabv.com.br/noticia/CIDADES/Capital/Venezuelanosatuam-em-papel-de-lideranca-no-crime-organizado-em-RR/72829 
Guerreiro, Ketiane, Gilmara Pinheiro de Andrade and Regys Odlare Freitas, 'O lúdico é matar: homicídio de jovens no estado de Roraima em 2018’. IBCCRIM, 2020, 1417-1438. Online: www.ibccrim.org.br/publicacoes/pagina/3

Humanitas Unisinos Institute, ‘Como o PCC se infiltrou nos garimpos em Roraima’, 13 May 2021. Online: www.ihu.unisinos.br/78-noticias/609206-como-o-pcc-se-infiltrou-nospanimpos-em-roraima

Insight Crime, 'Venezuela: ¿Un estado mafioso?’, 25 May 2018. Online: https://es.insightcrime. org/investigaciones/venezuela-estado-mafioso-2/

Insight Crime, 'Colombia y Venezuela: Siameses criminales’, 21 May 2018. Online: https:// es.insightcrime.org/investigaciones/colombia-y-venezuela-siameses-criminales/

Moya Sánchez, Thairi, 'Grupos civiles armados en Venezuela: ¿Actores de un 'aparato organizado de poder’?’. ANIDIP 6 (2018), 110-144. Online: http://doi.org/10.12804/ revistas.urosario.edu.co/anidip/a.7160

Observatorio Venezolano de Violencia, 'Bandas que operan al sur de Bolívar adoptan prácticas del pranato carcelario y de las mafias de la construcción’, 11 March 2016. Online: https:// observatoriodeviolencia.org.ve/news/bandas-que-operan-al-sur-de-bolivar-adoptanpracticas-del-pranato-carcelario-y-de-las-mafias-de-la-construccion/

Peres, Vitor Plácido dos Santos, ‘Análises de Conjuntura’, Grupo de Estudos e Pesquisas em Segurança Internacional (GEPSI), s. a. Online: http://gepsi.unb.br/index.php?option=com_ content\&view=article\&layout=edit\&id=61\&Itemid=599

Pimenta, Marília Carolina Barbosa de Souza, Strategic and Structural Zones for Illicit Transits (ZEETI): Challenges to the peace zone in South America. Doctoral thesis, PUC/SP, São Paulo, 2016.

Pipoli, Renzo, 'Venezuela on track to be Latin America’s most violent country in 2018'. UPI, 28 December 2018. Online: www.upi.com/Top_News/World-News/2018/12/28/Venezuelaon-track-to-be-Latin-Americas-most-violent-country-in-2018/1701546018259

Portugal Digital, 'Venezuela foi o país da América Latina com mais mortes violentas em 2020', 30 December 2020. Online: https://portugaldigital.com.br/venezuela-foi-o-pais-daamerica-latina-com-mais-mortes-violentas-em-2020/

Rodrigues, Thiago, 'Narcotráfico e militarização nas Américas: vício de guerra’. Contexto Internacional 34, no 1 (2012), 9-41. Online: https://doi.org/10.1590/S010285292012000100001

Teran Mantovani, Emiliano, 'La minería depredadora en Venezuela: Arco Minero del Orinoco, economías de enclave y Plan Minero Nacional’. Boletín WRM 254, January-February 2021. Online: https://wrm.org.uy/es/articulos-del-boletin-wrm/seccion1/la-mineriadepredadora-en-venezuela-arco-minero-del-orinoco-economias-de-enclave-y-plan-mineronacional/

TVV Noticias, ‘Luis Izquiel analiza el aumento de la violencia armada en Caracas’. Online: www.facebook.com/watch/?v=729160967746237

U.S. Department of State - Bureau of Consular Affairs, 'Travel Advisory - Venezuela', 28 January 2021. Online: https://travel.state.gov/content/travel/en/international-travel/ International-Travel-Country-Information-Pages/Venezuela.html\#/ 